\title{
Modeling the Socio-Economic Impacts of Covid-19 Using an Improved Traditional Travel Demand Model
}

\author{
Mehrnaz Doustmohammadi1 ${ }^{*}$, Phillip Ligrani' ${ }^{2}$, Michael Anderson ${ }^{1}$ \\ ${ }^{1}$ Department of Civil and Environmental Engineering, University of Alabama in Huntsville, Huntsville, USA \\ ${ }^{2}$ Department of Mechanical and Aerospace Engineering, University of Alabama in Huntsville, Huntsville, USA \\ Email: ^md0033@uah.edu
}

How to cite this paper: Doustmohammadi, M., Ligrani, P., \& Anderson, M. (2020). Modeling the Socio-Economic Impacts of Covid-19 Using an Improved Traditional Travel Demand Model. Current Urban Studies, 8, 688-704.

https://doi.org/10.4236/cus.2020.84037

Received: December 20, 2020

Accepted: December 28, 2020

Published: December 31, 2020

Copyright $\odot 2020$ by author(s) and Scientific Research Publishing Inc. This work is licensed under the Creative Commons Attribution International License (CC BY 4.0).

http://creativecommons.org/licenses/by/4.0/

\begin{abstract}
The emergence of the COVID-19 virus and subsequent pandemic has caused unprecedented disruption across many aspects of life across the globe. The implications have necessitated a re-evaluation of travel demand models to include the effects that mass isolation and quarantines have on roadway networks. The present paper is focused on data and methodologies to change travel demand models to account for differences encountered during the COVID-19 pandemic. Increased telecommunicating, coupled with store closures and restrictions, within the majority of business categories, has drastically changed traffic patterns. The results indicate that travel has decreased significantly, as businesses have altered their operating practices, requiring employees to work from home due to the restrictions implemented by the government. The present methodology considers a variety of potential alterations to travel patterns resulting from the presence of COVID-19. Because different amounts of reduced employment and increased telecommuting are considered, the present methodology and associated analysis show that different strategies proposed or implemented by the government can be modeled. The results provided in this paper, and the associated model, thus provide a means to account for the new traffic modelling reality resulting from the presence of COVID-19. Such travel modeling is important in regard to forecasts of future travel demand, associated transportation planning, allocation of present and future transportation resources, resulting economic benefits and challenges, and the well-being of our society, as an operationally efficient transportation network, and the associated quality of life, are maintained.
\end{abstract}

\section{Keywords}

COVID-19, Travel Modeling, Traffic Patterns, Traffic Planning 


\section{Background and Overview}

The presence of COVID-19 has resulted in overwhelming, and dramatic changes to the socio-economic structure of our society, not only within the United States, but for the entire world. Most every aspect and dimension of our lives have been altered including how and where we work, travel (Chakraborty \& Maity, 2020; Tirachini \& Cats, 2020; Gray, 2020), commute, shop, plan for the future, invest, and interact with other people (Srikanth, 2020). Because of these challenges, societal mobility (Chakraborty \& Maity, 2020; Tirachini \& Cats, 2020; Gray, 2020), quality of life (Korkmaz, Kazgan, Çekiç, Tartar, Balc1, \& Atmaca, 2020), investment strategies and goals, environmental status (Zambrano-Monserrate, Ruano, \& Sanchez-Alcalde, 2020; Gillingham, Knittel, Li, Ovaere, \& Reguant, 2020), economic development (Fernandes, 2020), and government financial directions and strategies (Altig, Baker, Barrero, Bloom, Bunn, Chen et al., 2020) have also been or will be modified significantly, relative to pre-coronavirus conditions. Personal travel has also been impacted in a plethora of ways for each possible travel destination. As a result, understanding how COVID-19 impacts community-wide travel patterns and behavior requires modified methodologies.

Examined within the present paper are: 1) changes to travel and trip making characteristics that reflect this new reality, and 2) a new methodology for trip generation, which employs existing data to model the new state of transportation. This improved and updated travel demand model demonstrates how traditional travel demand models can be altered and improved to account for new travel behavior. Within the present investigation, of particular interest are changes to societal mobility needs because of the advent of COVID-19. For example, a vast majority of people within the United States, in all walks-of-life, have drastically changed travel demand patterns. Also occurring are disruptions in travel and transportation services, both manmade and natural. As a result, our roadways and mass transit systems are currently running with varying degrees of reduced capacity, as well as with much reduced demand. Significant behavior changes resulting from the presence of COVID-19 are additionally illustrated by greater amounts and extents of telecommuting (working from home), on-line/ virtual schooling, reduced capacity in retail stores, closure of restaurants for in-house dining, self-quarantining to stay safe, and other items.

Accounting for such changes, with accurate and reliable travel demand model methodologies, is essential for maintaining quality of life. This is because such models are necessary for transportation planning. For example, urban transportation planning throughout the United States relies heavily on travel demand models for infrastructure investment. As such, the accuracy of the models is necessary to ensure good resource allocation, especially at the local governmental level, as travel demand modeling forecasts future congestion levels. Usable and accurate travel models thus support sound investment strategies and goals, as well as economic development, especially as such models represent the ability of 
transportation networks to transport goods, services, and people for a variety of operating and environmental conditions.

\section{Related Research}

Existing literature related to vehicle travel changes due to COVID-19 use one of two different approaches: (i) documentation of observed effects of COVID-19, or (ii) projection into the future regarding COVID-19 anticipated influences.

In regard to the first category (i), thehill.com (Srikanth, 2020) provides a map, provided by Streetlight Data (Real Time VMT by County, 2020) (a data collection company that uses machine learning to analyze transportation patterns), which shows how vehicle travel has dropped, as a consequence of stay-at-home orders. As of April 3, VMT (vehicle miles traveled) has gone down for most locations, with decreases by as much as 95 percent in some areas (Real Time VMT by County, 2020). Only a small number of locations indicated a rise in vehicle travel, with the largest increase of only 24 percent (Real Time VMT by County, 2020). An important and welcomed consequence of reduced travel was lower emissions. According to U.S. Public Interest Research Group (PIRG) (Dutzik, 2020), COVID-19 has made a significant dent in vehicle travel, and, as a result, reduced air pollution and decreased the loss of life and property from vehicle crashes. Assuming that vehicle travel remains at its current level for the rest of April, the COVID-19 crisis would result in at least a 5 percent decline in VMT for the whole of 2020 (Dutzik, 2020). CNBC (Kiesnoski, 2020) indicates that the COVID-19 pandemic has brought travel and tourism to a near-standstill and no one is sure when it will restart. The INRIX report (issue number 2) for March 21-27 (Schuman, 2020) shows dramatic US vehicle travel drop for all types of vehicles. Overall travel was down $38 \%$ for the week, relative to February 29, 2020 , and was down $18 \%$, relative to the previous week (Schuman, 2020). In contrast, the INRIX report (issue number 13) for June 6-12 (Schuman, 2020) indicates that overall vehicle travel continues to increase, relative to levels observed in late March and early April. In addition, considering vehicle travel throughout the entire US, the period of June 6 to June 12 showed that personal travel was down $7 \%$, compared to $12 \%$ for the previous week, long haul truck travel was down $3 \%$, compared to $3 \%$ for the previous week, and local fleets travel in metro areas was down $2 \%$, compared to $2 \%$ for the previous week (Schuman, 2020).

According to Streetsblog USA (Wilson, MilNeil, \& Snyder, 2020), millions of Americans gave up unnecessary driving travel in response to the COVID-19 outbreak. As a result, much car travel, that previously was commonplace, is now being avoided. Streetsblog also notes that much of these avoided trips may continue to be avoided, once the outbreak is over, often relatively painlessly. Many long-term consequences are noted, ranging from different travel patterns during bad weather, increased biking and walking, different levels of urbanization, and decreased air pollution (Wilson, MilNeil, \& Snyder, 2020). Blog.Mapbox (Heisler, 2020) indicates where and when local trips decreased from COVID-19 around 
the world. Telemetry visualizations of altered traffic patterns were provided by Mapbox Traffic data. Mapbox telemetry data comprised 16 billion anonymous location points a day, which were collected and aggregated for the purposes of improving information collections, observing real-time traffic, and predicting traffic based on historical observations. Because telemetry data was only collected from moving devices, not stationary ones, telemetry data also allowed observations of large-scale changes in movement. Important vehicle travel decreases were observed at most ever population center throughout the entire world, especially in Asia, Europe, North America, and South America. Travel times at different locations were also observed to decrease substantially.

According to USA Today (Bomey, 2020), the coronavirus pandemic is leading to reduced highway traffic on American roadways in certain major metropolitan areas as many people begin to telecommute and avoid social interactions. As a result, congestion is easing in places like New York, Los Angeles, Seattle and San Francisco, according to traffic figures provided exclusively to USA TODAY by HERE Technologies, a location data and technology company. "COVID-19 is having a rolling impact on traffic congestion across the U.S., with significant reductions in traffic levels seen across West Coast cities, with East Coast cities starting to see tangible drops as well," said Steve Harding, HERE's director of traffic and connected services. For example, the RTA, Rapid Transit Authority, of New Orleans, Louisiana (Coronavirus (COVID-19) Service Information, 2020), reduced bus, streetcar, and ferry services to help mitigate the spread of COVID-19. According to the Hindustan times (Covid-19 Lockdown Rules, 2020), with the implementation of COVID-19 lockdown 2.0 rules within India, only one passenger is allowed in each car. In addition, no riding pillion is permitted. Those who are permitted to move during the lockdown, only for providing essential services, must have just one person in any four-wheeled private vehicle, seated in the backseat, apart from the driver (Covid-19 Lockdown Rules, 2020).

In regard to the second category (ii), U.S. PIRG (Dutzik, 2020) speculates two different future scenarios: either, first, vehicle travel will experience a dramatic resurgence once restrictions begin to be lifted, or second, the hangover from the crisis will lead to travel reductions for the foreseeable future. The Los Angeles Times (Hamm, 2020) indicates that few things having to do with travel will be unchanged in the post-coronavirus world. However, the article also indicates that, from a regulatory standpoint, least affected may be the all-American road trip. According to CNBC (Kiesnoski, 2020), when travel does begin again, it is expected to start with road trips not too far from home. In addition, the new travel normal may mean a shift to vacation rentals over hotels, driving rather than flying, and an increase in the use of travel insurance and personal travel advisors.

The overall objective of the present investigation is modeling of future options and possibilities in regard to COVID-19 anticipated influences on vehicle travel. 


\section{Research Goals}

To develop appropriate travel demand model forecasts, the present paper focuses on a methodology to alter travel demand models to account for the present and future impacts of COVID-19. The investigation uses Huntsville, Alabama as a case study community. Addressed are changes to inputs reflecting socio-economic differences encountered due to COVID-19 restrictions. The resulting data are employed to determine differences in travel during a congested rush-hour time period. An example of socio-economic data affected by COVID-19 is the adjustment to employment data, obtained from the U.S. Census, wherein all non-retail employment, excluding essential facilities such as hospitals and clinics, are now staying at home. Also considered is the possibility that retail employment will also decrease. In addition, changes in schooling have altered travel behavior as more schools convert to on-line course delivery. Results of this analysis are related to activity on the roadway system, as quantified using expected alterations to trips generated and overall congestion. Factors considered to accommodate these observations are: 1) differences in telecommuting levels for different levels and timeframes, and 2) the impact of on-line schooling and changes in school operations.

Various levels of government, city, county, state and federal, have imposed restrictions for allowable capacity in businesses based on their classification and probability of spreading COVID-19. As a result, different scenarios are developed within the present investigation to determine the concomitant traffic patterns and congestion levels for the Huntsville, Alabama community. Note that these scenarios also serve as a demonstration of methodologies for the assessment of COVID-19 travel in future years, by incorporating a range of possible altered travel criteria. Such an approach provides means to address the possibilities of different future scenarios, ranging from societal shut-down to the complete disappearance of viral activities. With such a situation, travel patterns may or may not return to pre-virus conditions, such as were present prior to the arrival of the virus.

Overall goals and benefits of the present investigation are a modeling methodology to account for impacts of COVID-19 to the transportation system, with benefits in the form of reduced congestion and cost savings. Such cost savings are anticipated to result from improved development, use, and allocation of on-line and telecommuting patterns, with significant impacts on future transportation resource needs.

\section{Methodology}

The present methodology entails several parts. First, a preliminary model is developed, and then, adjusted to represent late afternoon peak hour conditions to account for traffic congestion within the study area. Second, relevant socio-economic data are collected to represent different time interval periods and to model mitigation strategies from the state Governor. Third, different scena- 
rios, related to employees across various employment categories, as well as school enrollment data, are used for the development of trip tables for each scenario. Fourth, a new trip table, related to late afternoon peak travel model distributions and assignments, is employed to analyze congestion statistics and to provide means to compare results associated with each scenario.

The travel demand model analyzes the city of Huntsville, Alabama. Huntsville is a medium-sized, urban community with a greater metropolitan area population of roughly 455,000 residents. The major industries in the community are related to aerospace and military sectors. The present research relies on the Huntsville Travel Demand Model, a standard sequential travel demand model which includes Trip Generation, Trip Distribution, and Traffic Assignment. This model contains 508 internal traffic analysis zones and 17 external stations.

The Huntsville, Alabama trip generation model was developed by the Alabama Department of Transportation (ALDOT) as a standalone software program. The Trip Distribution and Traffic Assignment steps are run using CUBE/ Voyager, Version 6.4 (Citilabs Inc.). For the present investigation, the original model is altered to reflect late afternoon peak hour conditions through the application of time-of-day parameters, obtained from the National Cooperative Highway Research Program (NCHRP) Report 365. The adjustment to a peak hour model is done to better capture congestion effects. This is because the model includes limited congested during the off peak periods, and the use of a 24-hour model would not provide data which is appropriately representative of the impact of COVID-19 conditions. Note that the original model is validated using base year traffic forecasts. The model also gives levels of accuracy which are consistent with Federal Highway Administration guidelines.

The second step in the methodology involves collection of relevant socio-economic data for modeling analysis. The Governor of Alabama issued a stay-at-home, amended safer-at-home, and safer-apart guidelines identifying closures and reduced capacities for all kinds of employment categories. These provide the basis of the travel pattern reductions for the present analysis. The corresponding Alabama orders are shown in Figure 1. In addition to these state rules regarding travel to work and other closures, employment data and school enrollment data for the Huntsville urbanized area are also collected. These employment data are obtained from the US Census Department through the Longitudinal Employer-Household Dynamics (LEHD) program. Such employment data are available at the Census Block Level, and are identified by 20 unique employment types defined by the North American Industry Classification System (NAICS). Employment by census block information is aggregated using ArcGIS to convert employment data from census blocks to each of the 508 internal traffic analysis zones in the community. School enrollment data are acquired from the original data collection effort used to create and validate the original travel demand model. 


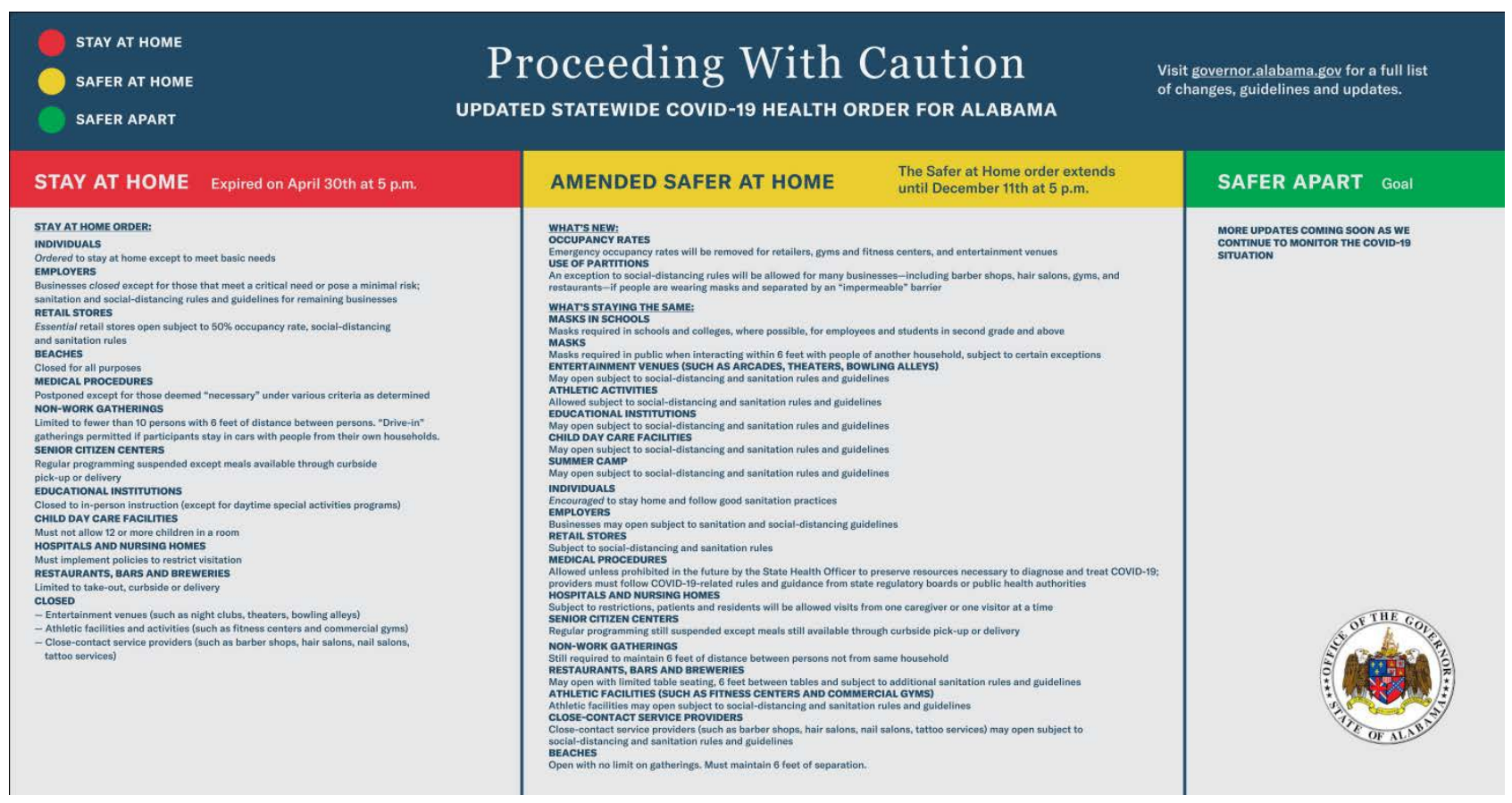

Figure 1. Statewide COVID-19 health orders for Alabama (COVID-19 News and Resources, 2020).

The orders from the Alabama Governor's Office (given in Figure 1) are used to adjust employment and school enrollment data for each traffic zone to create the different scenarios employed within the present research. Due to the travel demand model's trip generation methodology, the zonal attraction values for employment and education zones are reduced leading to a reduction in trips generated to these destinations. This captures the number of employees that are likely to be at work and the number of students likely to be attending school. Note that the reductions in employment and school enrollment are not necessarily identified to indicate termination of employment or school enrollment. Instead, reductions indicate that some employees or students do not travel to the associated destination because of travel restrictions for the relevant time period.

For each case, an extreme scenario is developed to provide information in addition to corresponding normal scenario data. The times for which scenarios are developed include the original stay-at-home order, which was provided in March of 2020, and the amended safer-at-home order, which was provided in July of 2020. Also included is the Fall 2020 time period, when it is assumed that more businesses are open and there are more work-related trips generated, and finally, the Winter 2021 time period, when it is assumed that there will be a vaccine available, with only a small portion of vehicle-travelling people expected continuing to work from home. For the Fall 2020 and Winter 2021 scenarios, different levels of school enrollment are included to account for different student school opening options. For example, some students may elect on-line instruction, instead of traditional classroom attendance. Such an arrangement is available for, and may be preferred by students, because of additional COVID-19 re- 
surgence concerns, and because of the possibility that schools will be forced to remain closed.

The resulting scenarios developed for each analysis option are provided in Tables 1-4.

Table 1. Capacity of trips associated with Stay-at-home Scenarios for March 2020, April 2020, and May 2020.

\begin{tabular}{|c|c|c|c|}
\hline & & Stay-at-home & Stay-at-home Extreme \\
\hline \multirow{6}{*}{$\begin{array}{l}\text { Non-retail } \\
\text { Employment }\end{array}$} & NAICS sector 11-Agriculture, Forestry, Fishing, Hunting & Full Capacity & Full Capacity \\
\hline & NAICS sector 21-Mining Quarrying, and Oil and Gas Extraction & Full Capacity & Full Capacity \\
\hline & NAICS sector 22-Utilities & Full Capacity & Full Capacity \\
\hline & NAICS sector 23-Construction & Full Capacity & Full Capacity \\
\hline & NAICS sector 31 - 33-Manufacturing & Full Capacity & Full Capacity \\
\hline & NAICS sector $42-$ Wholesale Trades & 0.5 & 0.2 \\
\hline \multirow[t]{7}{*}{ Retail } & NAICS sector 44 - 45-Retail Trade & 0.3 & 0.2 \\
\hline & NAICS sector 48 - 49-Transportation and Warehousing & 0.5 & 0.2 \\
\hline & NAICS sector 51-Information & 0 & 0 \\
\hline & NAICS sector 52-Finance and Insurance & 0 & 0 \\
\hline & NAICS sector 53-Real Estate and Rental and Leasing & 0 & 0 \\
\hline & NAICS sector 54-Professional, Scientific and Technical Services & 0.2 & 0.1 \\
\hline & NAICS sector 55-Management of Companies and Enterprises & 0.2 & 0.1 \\
\hline \multirow{7}{*}{$\begin{array}{l}\text { Non-retail } \\
\text { Employment }\end{array}$} & $\begin{array}{l}\text { NAICS sector 56-Administrative and Support and Waste } \\
\text { Management and Remediation Services }\end{array}$ & 0.2 & 0.1 \\
\hline & NAICS sector 61-Educational Services & 0 & 0 \\
\hline & NAICS sector 62-Health Care and Social Assistance & 0.4 & 0.2 \\
\hline & NAICS sector 71-Arts, Entertainment and Recreation & 0 & 0 \\
\hline & NAICS sector 72-Accommodations and Food Services & 0.2 & 0.2 \\
\hline & NAICS sector 81-Other Services (except Public Administration) & 0.2 & 0.1 \\
\hline & NAICS sector 92-Public Administration & 0.1 & 0.1 \\
\hline
\end{tabular}

Table 2. Capacity of trips associated with Safer at Home Scenarios for June 2020, July 2020, and August 2020.

\begin{tabular}{cllr}
\hline & & Safer at Home & Safer at Home_Extreme \\
\hline & NAICS sector 11-Agriculture, Forestry, Fishing, Hunting & Full Capacity & Full Capacity \\
& NAICS sector 21-Mining Quarrying, and Oil and Gas Extraction & Full Capacity & Full Capacity \\
$\begin{array}{c}\text { Non-retail } \\
\text { Employment }\end{array}$ & NAICS sector 22-Utilities & Full Capacity & Full Capacity \\
& NAICS sector 23-Construction & Full Capacity & Full Capacity \\
& NAICS sector $31-33-$ Manufacturing & Full Capacity & Full Capacity \\
\hline Retail & NAICS sector $42-$ Wholesale Trades & 0.5 & 0.4 \\
\hline
\end{tabular}




\section{Continued}

$\begin{array}{llll} & \text { NAICS sector 48 - 49-Transportation and Warehousing } & 0.6 & 0.5 \\ & \text { NAICS sector 51-Information } & 0.6 & 0.5 \\ & \text { NAICS sector 52-Finance and Insurance } & 0.4 & 0.2 \\ & \text { NAICS sector 53-Real Estate and Rental and Leasing } & 0.4 & 0.2 \\ & \text { NAICS sector 54-Professional, Scientific and Technical Services } & 0.4 & 0.3 \\ & \text { NAICS sector 55-Management of Companies and Enterprises } & 0.4 & 0.3 \\ \text { Non-retail } & \text { NAICS sector 56-Administrative and Support and Waste } & & 0.3 \\ & \text { Management and Remediation Services } & 0.4 & 0.2 \\ & \text { NAICS sector 61-Educational Services } & & 0.3 \\ & \text { NAICS sector 62-Health Care and Social Assistance } & 0.3 & 0.5 \\ & \text { NAICS sector 71-Arts, Entertainment and Recreation } & 0.6 & 0.2 \\ & \text { NAICS sector 72-Accommodations and Food Services } & 0.3 & 0.3 \\ & \text { NAICS sector 81-Other Services (except Public Administration) } & 0.6 & 0.3\end{array}$

Table 3. Capacity of trips associated with Safer at Home Scenarios for September 2020, October 2020, and November 2020.

\begin{tabular}{|c|c|c|c|}
\hline & & Safer at Home & Safer at Home_Extreme \\
\hline \multirow{6}{*}{$\begin{array}{l}\text { Non-retail } \\
\text { Employment }\end{array}$} & NAICS sector 11-Agriculture, Forestry, Fishing, Hunting & Full Capacity & Full Capacity \\
\hline & NAICS sector 21-Mining Quarrying, and Oil and Gas Extraction & Full Capacity & Full Capacity \\
\hline & NAICS sector 22-Utilities & Full Capacity & Full Capacity \\
\hline & NAICS sector 23-Construction & Full Capacity & Full Capacity \\
\hline & NAICS sector 31 - 33-Manufacturing & Full Capacity & Full Capacity \\
\hline & NAICS sector 42-Wholesale Trades & 0.7 & 0.6 \\
\hline Retail & NAICS sector 44 - 45-Retail Trade & 0.7 & 0.6 \\
\hline \multirow{13}{*}{$\begin{array}{l}\text { Non-retail } \\
\text { Employment }\end{array}$} & NAICS sector 48 - 49-Transportation and Warehousing & 0.7 & 0.6 \\
\hline & NAICS sector 51-Information & 0.7 & 0.6 \\
\hline & NAICS sector 52-Finance and Insurance & 0.7 & 0.6 \\
\hline & NAICS sector 53-Real Estate and Rental and Leasing & 0.5 & 0.4 \\
\hline & NAICS sector 54-Professional, Scientific and Technical Services & 0.5 & 0.4 \\
\hline & NAICS sector 55-Management of Companies and Enterprises & 0.5 & 0.4 \\
\hline & $\begin{array}{l}\text { NAICS sector 56-Administrative and Support and Waste } \\
\text { Management and Remediation Services }\end{array}$ & 0.6 & 0.5 \\
\hline & NAICS sector 61-Educational Services & 0.4 & 0.3 \\
\hline & NAICS sector 62-Health Care and Social Assistance & 0.7 & 0.6 \\
\hline & NAICS sector 71-Arts, Entertainment and Recreation & 0.4 & 0.3 \\
\hline & NAICS sector 72-Accommodations and Food Services & 0.7 & 0.6 \\
\hline & NAICS sector 81-Other Services (except Public Administration) & 0.5 & 0.4 \\
\hline & NAICS sector 92-Public Administration & 0.5 & 0.4 \\
\hline
\end{tabular}


Table 4. Capacity of trips associated with Safer at Home Scenarios for December 2020, January 2021, and Februrary 2021.

\begin{tabular}{|c|c|c|c|}
\hline & & Safer at Home & Safer at Home_Extreme \\
\hline \multirow{6}{*}{$\begin{array}{l}\text { Non-retail } \\
\text { Employment }\end{array}$} & NAICS sector 11-Agriculture, Forestry, Fishing, Hunting & Full Capacity & Full Capacity \\
\hline & NAICS sector 21-Mining Quarrying, and Oil and Gas Extraction & Full Capacity & Full Capacity \\
\hline & NAICS sector 22-Utilities & Full Capacity & Full Capacity \\
\hline & NAICS sector 23-Construction & Full Capacity & Full Capacity \\
\hline & NAICS sector 31 - 33-Manufacturing & Full Capacity & Full Capacity \\
\hline & NAICS sector $42-$ Wholesale Trades & 0.9 & 0.8 \\
\hline \multirow[t]{7}{*}{ Retail } & NAICS sector 44 - 45-Retail Trade & 0.9 & 0.8 \\
\hline & NAICS sector 48 - 49-Transportation and Warehousing & 0.8 & 0.7 \\
\hline & NAICS sector 51-Information & 0.8 & 0.8 \\
\hline & NAICS sector 52-Finance and Insurance & 0.8 & 0.7 \\
\hline & NAICS sector 53-Real Estate and Rental and Leasing & 0.8 & 0.7 \\
\hline & NAICS sector 54-Professional, Scientific and Technical Services & 0.9 & 0.8 \\
\hline & NAICS sector 55-Management of Companies and Enterprises & 0.7 & 0.6 \\
\hline \multirow[t]{7}{*}{$\begin{array}{l}\text { Non-retail } \\
\text { Employment }\end{array}$} & $\begin{array}{l}\text { NAICS sector 56-Administrative and Support and Waste } \\
\text { Management and Remediation Services }\end{array}$ & 0.8 & 0.7 \\
\hline & NAICS sector 61-Educational Services & 0.8 & 0.7 \\
\hline & NAICS sector 62-Health Care and Social Assistance & 0.9 & 0.8 \\
\hline & NAICS sector 71-Arts, Entertainment and Recreation & 0.4 & 0.3 \\
\hline & NAICS sector 72-Accommodations and Food Services & 0.9 & 0.7 \\
\hline & NAICS sector 81-Other Services (except Public Administration) & 0.7 & 0.6 \\
\hline & NAICS sector 92-Public Administration & 0.7 & 0.6 \\
\hline
\end{tabular}

Results in Tables 1-4 show that certain employment categories do not experience significant changes due to COVID-19. Considering reductions in travel due to people not working or being allowed to telecommute, it is assumed that other employees (in certain types of employment categories) are required to be on-site to meet the requirements. For example, there are no restrictions in the mining or construction industries mandated by either the stay-at-home order or by the safer-at-home order. Alternatively, retail employment is identified separately in the tables because this type of employment is the major contributor of overall Home-Based-Other ( $\mathrm{HBO}$ ) related trips.

The third step in the methodology is the creation of trip tables, using trip generation equations, as well as employment and school enrollment data, as determined per traffic zone. Overall, 16 new scenarios are developed, as presented in Table 5, for the two time periods of Fall 2020 and Winter 2021. For each time period, normal and extreme reductions of school enrollment are considered, with three different levels of in-class attendance. With such considerations in mind, the data for each traffic zone are adjusted to give the number of individuals 
Table 5. Socio-economic scenario possibilities for Fall of 2020 and Winter of 2021 time periods.

\begin{tabular}{|c|c|}
\hline Stay-at-home & Extreme Stay-at-home \\
\hline Safer-at-home & Extreme Safer-at-home \\
\hline $\begin{array}{l}\text { Fall } 2020 \text { - no school-all kids in on-line } \\
\text { school, } 0 \% \text { of all children in school }\end{array}$ & $\begin{array}{l}\text { Extreme Fall } 2020 \text {-no school-all kids in } \\
\text { on-line school, } 0 \% \text { of all children in school }\end{array}$ \\
\hline $\begin{array}{l}\text { Fall } 2020-50 \text { school }-50 \% \text { of all children } \\
\text { in school }\end{array}$ & $\begin{array}{l}\text { Extreme Fall } 2020-50 \text { school }-50 \% \text { of all } \\
\text { children in school }\end{array}$ \\
\hline $\begin{array}{l}\text { Fall } 2020-100 \text { school }-100 \% \text { of all children } \\
\text { in school }\end{array}$ & $\begin{array}{l}\text { Extreme Fall } 2020-100 \text { school }-100 \% \text { of } \\
\text { all children in school }\end{array}$ \\
\hline $\begin{array}{l}\text { Winter } 2020-\text { no school-all kids in on-line } \\
\text { school, } 0 \% \text { of all children in school }\end{array}$ & $\begin{array}{l}\text { Extreme Winter } 2020 \text {-no school-all kids in } \\
\text { on-line school, } 0 \% \text { of all children in school }\end{array}$ \\
\hline $\begin{array}{l}\text { Winter } 2020-50 \text { school }-50 \% \text { of all children } \\
\text { in school }\end{array}$ & $\begin{array}{l}\text { Extreme Winter } 2020-50 \text { school }-50 \% \text { of all } \\
\text { children in school }\end{array}$ \\
\hline $\begin{array}{l}\text { Winter } 2020-100 \text { school }-100 \% \text { of all } \\
\text { children in school }\end{array}$ & $\begin{array}{l}\text { Extreme Winter } 2020-100 \text { school }-100 \% \\
\text { of all children in school }\end{array}$ \\
\hline
\end{tabular}

who are traveling, in order to determine the number of trips associated with Home-Based-Work (HBW), Home-Based-Other (HBO), and Non-Home-Based (NHB) activities. Associated trip generation equations are then used to calculate the total number of trips attracted to each zone during each scenario. The total number of trip productions is then balanced with the total number of trip attractions, and subsequently, normalized to ensure that each trip from a home has a destination attracting the trip.

The final and fourth step of the methodology is the distribution and assignment of trip table contents. These contents are related to late afternoon peak travel model distributions and assignments, as employed to analyze congestion statistics and to provide means to compare results associated with each scenario. Trip tables containing zonal production and attraction values are formatted, and a gravity model distribution and equilibrium traffic assignment are performed for each scenario.

Note that traffic modelling results from the scenario-specific trip tables are considered in the next section and that the steps in the present methodology can be used by any planning organization. In addition, values selected to represent trip number reductions for each employment category, and school enrollment number reductions, may be decided by an agency's traffic planner. As such, specific and appropriate numbers of trip reductions and increases can be determined and evaluated for any community of interest.

\section{Relevance and Importance of Results}

Importance and relevance are illustrated by several crucial questions. First, if the employers ask their employees to work from home, does that mean the traffic 
congestion will decrease? Second, if the employers ask their employees to work from home, does that mean the future of traffic analysis has changed forever? Third, considering overall and diverse effects and impacts, should we reallocate resources to other aspects like safety instead?

In order to partially address these questions, Table 6 indicates the number of trips associated with Home-Based-Work (HBW), Home-Based-Other (HBO), and Non-Home-Based (NHB). These are categorized according to 17 possible scenarios associated with the congestion metrics, including base conditions, stay-at-home, extreme-stay-at-home, safer-at-home, extreme safer-at-home, as well as all of the socio-economic scenario possibilities listed in Table 6. Within these possibilities, the extreme cases are created within Table 6 to provide a description regarding the most significant changes to traffic congestion metrics, which could occur within two different time periods of the pandemic.

The results in Table 6 show that, first, Home-Based-Work trips decrease significantly as a result of employees not traveling to work. Because the model directly relates work trips to employment and to traveling to work, any reduction in employment, or increase in employees telecommuting (and not traveling to employment locations), alters the number of HBW trips in a direct manner. For example, the extreme-stay-at-home scenario is associated with an overall telecommute or unemployment value of $78 \%$ of the workforce, compared to $78 \%$

Table 6. VMT data associated with different socio-economic scenario possibilities for Fall of 2020 and Winter of 2021 time periods.

\begin{tabular}{|c|c|c|c|c|c|c|}
\hline Scenario & HBW Trips & HBO Trips & NHB Trips & VMT & VHD & MCR \\
\hline Base Conditions & 147,643 & 560,583 & 291,809 & $1,625,676$ miles & 15,684 hours & 404 miles \\
\hline Stay at Home & 45,347 & 201,593 & 115,986 & 541,886 miles & 283 hours & 13 miles \\
\hline Extreme Stay at Home & 31,269 & 157,722 & 91,143 & 401,215 miles & 99 hours & 0 miles \\
\hline Safer at Home & 67,206 & 254,049 & 144,725 & 740,856 miles & 952 hours & 45 miles \\
\hline Extreme Safer at Home & 52,920 & 209.605 & 119,812 & 597,409 miles & 432 hours & 24 miles \\
\hline Fall 2020-no school & 74,658 & 261,872 & 148,728 & 799,400 miles & 1270 hours & 57 miles \\
\hline Fall $2020-50$ school & & 284,444 & & 808,613 miles & 1305 hours & 59 miles \\
\hline Fall 2020-100 school & & 307,017 & & 817,850 miles & 1345 hours & 61 miles \\
\hline Extreme Fall 2020-no school & 69,131 & 256,225 & 145,845 & 755,347 miles & 1030 hours & 48 miles \\
\hline Extreme Fall 2020-50 school & & 278,769 & & 765,079 miles & 1044 hours & 48 miles \\
\hline Extreme Fall 2020-100 school & & 301,351 & & 774,209 miles & 1073 hours & 49 miles \\
\hline Winter $2020-$ no school & 130,273 & 467,845 & 265,271 & $1,417,772$ miles & 9937 hours & 301 miles \\
\hline Winter $2020-50$ school & & 490,432 & & $1,432,622$ miles & 10,319 hours & 308 miles \\
\hline Winter $2020-100$ school & & 512,984 & & $1,442,877$ miles & 10,489 hours & 319 miles \\
\hline Extreme Winter 2020-no school & 114,951 & 422,359 & 239,820 & $1,260,616$ miles & 6638 hours & 233 miles \\
\hline Extreme Winter $2020-50$ school & & 444,952 & & $1,267,697$ miles & 6617 hours & 240 miles \\
\hline Extreme Winter $2020-100$ school & & 467,500 & & $1,275,557$ miles & 6634 hours & 241 miles \\
\hline
\end{tabular}


reduction in work trips. Such values are also affected by the unemployment rate, which, for Alabama in April of 2020, was approximately 13\% (Alabama's Unemployment Rate, 2020). Consideration of extreme scenarios for the Winter of 2021 shows that $12 \%$ of the population will either telecommute or not travel to work, for a direct reduction in work trips also of $12 \%$.

The results in Table 6 also show, secondly, that Home-Based-Other trips decrease less dramatically as a result of employees not traveling to work. This is because relationships between work trips, employment, and other trips are not linear. Instead, such trips are related to the number of people at the work location. Examination of the extreme-stay-at-home scenario indicates that a $78 \%$ reduction in workforce exhibits a $72 \%$ reduction for Home-Based-Other trips. The key contributor of these trips is retail employment, and model logic indicates that each retail employee is responsible for multiple trips. As retail employees return to work, the number of trips is expected to grow, partially because a large portion of retail trips are generally not likely to be accomplished through telecommunication. As a result, these trips are expected to return to near pre-COVID-19 levels, with only an $8 \%$ reduction in trips associated with the return of $90 \%$ of retail employees to work. Table 6 also indicates that, considering the Fall 2020 and Winter 2021 scenarios, a direct impact on vehicle travel related to school enrollment is present. Should schools host in-person classes for the fall semester, a direct increase of 45,000 trips are expected, compared to the number of trips associated with the previous spring 2020 time period. These trips are, of course, associated with transportation of children to and from to school, either by the children themselves, or by their parents.

A third conclusion from the contents of Table 6 is that Non-Home-Based trips are also closely linked to retail employment. The numbers of associated trips are generally a result of trip-chaining between retail stores and midday trips for lunch and errands by individuals, as they travel to and from their employment locations. Differences in associated trip numbers associated with the Fall of 2020, for observed scenarios, further show that the extreme-stay-at-home gives a NHB trip number reduction of $69 \%$, whereas a reduction of only $9 \%$ is associated with the Winter of 2021.

Fourth, Table 6 data also indicate that vehicle miles of travel (VMT) show significant reductions for the stay-at-home scenario and for the extreme stay-at-home scenario (both for March of 2020), relative to base conditions (for January of 2020). Associated data are given in Figure 2, which includes data for both the stay-at-home scenario and the extreme stay-at-home scenario. These values show a gradual increase in VMT as time increase further after March of 2020. Numbers of VMT then approach pre-COVID-19 conditions as January of 2021 is approached.

A fifth collection of important observations are associated with vehicle hours of delay (VHD) and miles of congested roadway (MCR). Both of these quantities show significant reductions for every COVID-19 scenario considered. Stay-at-home 


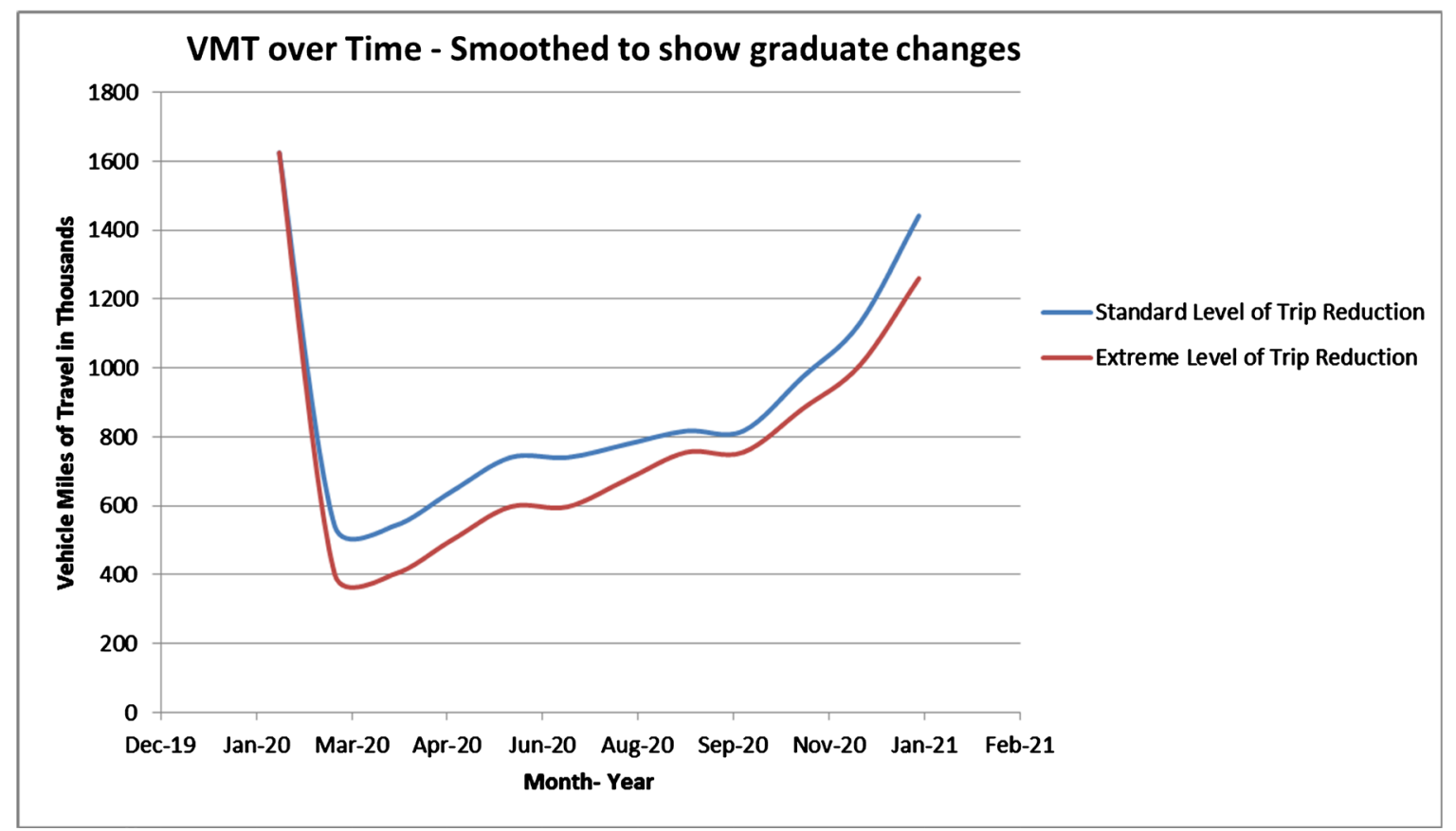

Figure 2. Modelled VMT variations with time from January 2020 to January 2021.

scenarios result in reduced VHD to almost zero, with the exception of a few isolated community locations. With the Winter 2021 scenarios, VHD returns to roughly $66 \%$ of base condition values. This is interesting because an $11 \%$ reduction in vehicle miles travelled VMT leads to a 33\% reduction in VHD. This indicates that even a relatively small increase in telecommuting results in a significant reduction in VHD, along with overall transportation system performance improvements. While the telecommuting impact on miles of congested roadways is not as great, the $11 \%$ reduction in VMT yields a $21 \%$ reduction in miles of congested roadway. Such results provide further illustration that the Huntsville, Alabama area network operated at slightly over maximum capacity during pre-COVID-19 scenario conditions.

The stay-at-home and extreme stay-at-home scenarios are thus attributed to severe reductions in vehicle miles traveled and delay imposed. This is due to the fact that employment changes drastically during these scenarios which remove vehicles from the roadway. The reduction in retail employment due to closures and layoffs also reduces the overall number of trips generated as drivers seem to visit these locations originating from a work-based location. There is a direct correlation to HBW trip reductions to reduction in employment and increases in telecommuting with a lesser effect seen within HBO trips.

\section{Summary and Conclusion}

The present paper demonstrates alteration of travel demand models to account for changes in travel patterns due to the COVID-19 pandemic for the Huntsville, Alabama community. As discussed, a variety of telecommuting and on-line 
schooling options are under consideration by local jurisdictions, which are also being accommodated by altered business work environments. Until the COVID-19 virus is understood and a vaccine that provides immunity is developed and distributed, a considerable variety of possible scenarios, with a wide variety of traffic and travel behavioral characteristics, will be possible.

The present methodology considers a variety of potential alterations to travel patterns resulting from the presence of COVID-19. Because different amounts of reduced employment and increased telecommuting are considered, the present methodology, and associated analysis, show that different strategies proposed or implemented by the government can be modeled. The results provided in this paper, and the associated model, thus provide a means to account for the new traffic modelling reality resulting from the presence of COVID-19.

In particular, results indicate a non-linear relationship between increases in telecommuting and reduction in travel delay, as indicated by variations of vehicle hours of delay (VHD), and miles of congested roadway (MCR). Also important are significant reductions in travel from the COVID-19 pandemic, which result in smaller fuel tax collections, as well as the reductions of the associated revenue dollars for roadway infrastructure projects. A positive attribute evidenced by the present results is smaller roadway demand levels and reduced congestion, which is also a consequence of diminished travel and transportation needs. It is noted that, if the pandemic passes, with a full return to employment, traffic congestion levels may return to pre-COVID-19 levels, resulting in a traffic environment with additional negative consequences and new challenges.

Of particular focus in this work are associated with changes in travel demand, as determined by modeling. Such travel modeling is important in regard to forecasts of travel demand for the future to ensure transportation infrastructure is able to meet associated demands. Associated planning is additionally vital in regard to the economic benefits in the form of potential cost savings, which result from improved development, use, and allocation of present and future transportation resources. The overall benefits of the present research results are thus tied to the well-being of our society, as an operationally efficient transportation network, and the associated quality of life, are maintained.

\section{Conflicts of Interest}

The authors declare no conflicts of interest regarding the publication of this paper.

\section{References}

Alabama's Unemployment Rate (2020). Alabama's Unemployment Rate for April Is 12.9\%. https://hsvchamber.org/alabamas-unemployment-rate-for-april-is-12-9

Altig, D., Baker, S., Barrero, J. M., Bloom, N., Bunn, P., Chen, S., Mizen, P. et al. (2020). Economic Uncertainty before and during the COVID-19 Pandemic. Journal of Public Economics, 191, Article ID: 104274. https://doi.org/10.1016/j.jpubeco.2020.104274 
Bomey, N. (2020). Highway Traffic Is Plunging in These US Cities amid Coronavirus Pandemic.

https://www.usatoday.com/story/money/cars/2020/03/13/coronavirus-pandemic-crater ing-road-traffic-these-us-cities/5041250002

Chakraborty, I., \& Maity, P. (2020). COVID-19 Outbreak: Migration, Effects on Society, Global Environment and Prevention. Science of the Total Environment, 728, Article ID: 138882. https://doi.org/10.1016/j.scitotenv.2020.138882

Coronavirus (COVID-19) Service Information. https://www.norta.com/COVID19

Covid-19 Lockdown Rules (2020). In Covid-19 Lockdown 2.0 Rules, Only One Passenger in Car and No Riding Pillion.

COVID-19 News and Resources (2020). COVID-19 News and Resources. https://governor.alabama.gov/newsroom/COVID-19

Dutzik, T. (2020). America on Pause: Vehicle Travel during COVID-19 and What Comes Next.

https://uspirg.org/blogs/blog/usp/america-pause-vehicle-travel-during-covid-19-and-w hat-comes-next

Fernandes, N. (2020). Economic Effects of Coronavirus Outbreak (COVID-19) on the World Economy. https://doi.org/10.2139/ssrn.3557504

Gillingham, K. T., Knittel, C. R., Li, J., Ovaere, M., \& Reguant, M. (2020). The Short-Run and Long-Run Effects of Covid-19 on Energy and the Environment. Joule, 4, 1337-1341. https://doi.org/10.1016/j.joule.2020.06.010

Gray, R. S. (2020). Agriculture, Transportation, and the COVID-19 Crisis. Canadian Journal of Agricultural Economics. https://doi.org/10.1111/cjag.12235

Hamm, C. (2020). After Coronavirus: Your Next Road Trip May Look like This. https://www.latimes.com/travel/story/2020-05-05/after-coronavirus-taking-car-road-tr ip

Heisler, S. (2020). Where and When Local Travel Decreased from COVID-19 around the World.

https://blog.mapbox.com/movement-changes-around-the-world-from-COVID-19-cc7 $\underline{9 \mathrm{db} 7 \mathrm{e} 04 \mathrm{c} 7}$

Kiesnoski, K. (2020). Travel Changed after 9/11; Here's How It Will Look after the Covid-19 Pandemic Finally Recedes.

https://www.cnbc.com/2020/05/10/heres-how-travel-will-change-after-the-covid-19-pa ndemic-recedes.html

Korkmaz, S., Kazgan, A., Çekiç, S., Tartar, A. S., Balcı, H. N., \& Atmaca, M. (2020). The Anxiety Levels, Quality of Sleep and Life and Problem-Solving Skills in Healthcare Workers Employed in COVID-19 Services. Journal of Clinical Neuroscience, 80, 131-136. https://doi.org/10.1016/j.jocn.2020.07.073

Real Time VMT by County. https://www.streetlightdata.com/VMT-monitor-by-county/?fbclid=IwAR0zFtC9G9XeI Jh2zUqvUDgr3OBQx9vzYm-H3udjca2XRE6_cwdjUBfYl7g\#emergency-map-response

Schuman, R. (2020). INRIX U.S. National Traffic Volume Synopsis Issue \#13. https://inrix.com/blog/2020/06/inrix-u-s-national-traffic-volume-synopsis-issue-13-ju ne-6-june-12-2020

Schuman, R. (2020). INRIX U.S. National Traffic Volume Synopsis: Issue \#2. https://inrix.com/blog/2020/03/COVID19-us-traffic-volume-synopsis-2

Srikanth, A. (2020). This Map Shows How Much Vehicle Travel Has Dropped Due to Coronavirus. 
Tirachini, A., \& Cats, O. (2020). COVID-19 and Public Transportation: Current Assessment, Prospects, and Research Needs. Journal of Public Transportation, 22, 1.

https://doi.org/10.5038/2375-0901.22.1.1

Wilson, K., MilNeil, C., \& Snyder, T. (2020). COVID19 Legacy: The Death of the Avoidable Car Trip?

https://usa.streetsblog.org/2020/03/23/COVID19-legacy-the-death-of-the-avoidable-ca r-trip

Zambrano-Monserrate, M. A., Ruano, M. A., \& Sanchez-Alcalde, L. (2020). Indirect Effects of COVID-19 on the Environment. Science of the Total Environment, 728, Article ID: 138813. https://doi.org/10.1016/j.scitotenv.2020.138813 